\title{
CCR5 32 Deletion as a Protective Factor in Czech First-Wave COVID-19 Subjects
}

\author{
Jaroslav A. HUBACEK ${ }^{1,2}$, Ladislav DUSEK ${ }^{3,4}$, Ondrej MAJEK ${ }^{3,4}$, Vaclav ADAMEK ${ }^{5}$, Tereza \\ CERVINKOVA $^{6}$, Dana DLOUHA ${ }^{1}$, Jozef PAVEL ${ }^{1}$, Vera ADAMKOVA ${ }^{5,6}$ \\ ${ }^{1}$ Experimental Medicine Centre, Institute for Clinical and Experimental Medicine, Prague, Czech \\ Republic, ${ }^{2}$ Third Department of Internal Medicine, First Faculty of Medicine, Charles University, \\ Prague, Czech Republic, ${ }^{3}$ Institute of Health Information and Statistics of the Czech Republic, \\ Prague, Czech Republic, ${ }^{4}$ Institute of Biostatistics and Analyses, Faculty of Medicine, Masaryk \\ University, Brno, Czech Republic, ${ }^{5}$ Czech Technical University, Faculty of Biomedical \\ Engineering, Kladno, Czech Republic, ${ }^{6}$ Department of Preventive Cardiology, Institute for Clinical \\ and Experimental Medicine, Prague, Czech Republic
}

Received January 21, 2021

Accepted January 22, 2021

\section{Summary}

Infection by severe acute respiratory syndrome coronavirus 2 (SARS-CoV-2), the virus that causes coronavirus disease (COVID-19), has spread widely around the globe. Significant inter-individual differences have been observed during the course of the infection, which suggests that genetic susceptibility may be a contributing factor. CC chemokine receptor 5 (CCR5), which acts as a co-receptor for the entry of HIV-1 into cells, is promising candidate whose can have an influence on SARS-CoV-2 infection. A genetic mutation known as CCR5 $\triangle 32$, consisting of a 32-nucleotide deletion, encodes a truncated protein that protects homozygous carriers of the deletion from HIV-1 infection. Similarly, inhibition of CCR5 seems to be protective against COVID-19. In our study, we successfully genotyped 416 first-wave SARS-CoV-2-positive infection survivors (164 asymptomatic and 252 symptomatic) for CCR5 32 , comparing them with a population based sample of 2,404 subjects. We found the highest number $(P=0.03)$ of CCR5 32 carriers in SARS-CoV-2-positive/COVID-19-asymptomatic subjects (23.8 \%) and the lowest number in SARS-CoV-2positive/COVID-19-symptomatic patients (16.7\%), with frequency in the control population in the middle $(21.0 \%)$. We conclude that the CCR5 $32 \mathrm{I} / \mathrm{D}$ polymorphism may have the potential to predict the severity of SARS-CoV-2 infection.

\section{Key words}

COVID-19 • CCR5 • Polymorphism • Deletion • $\Delta 32$

\section{Corresponding author}

J. A. Hubacek, Experimental Medicine Centre, Institute for Clinical and Experimental Medicine, Videnska 1958/9, 14021 Prague 4, Czech Republic. E-mail: jahb@ikem.cz

Infection by severe acute respiratory syndrome coronavirus 2 (SARS-CoV-2) is an emerging, rapidly evolving situation affecting millions of subjects worldwide (Berekaa 2020). Caused by the SARS-CoV-2 infection, COVID-19 differs from previously occurring SARS and MERS infections in that it is far more infectious but significantly less lethal.

Importantly, significant geographic and ethnic variations in COVID-19 prevalence and mortality have been observed (Hippisley-Cox et al. 2020). Similar to other communicable diseases (Casanova 2015), genetic predispositions may at least partly explain the differences ascribed to COVID-19 to date (Vašků 2020, Elhabyan et al. 2020). However, the number of studies to have investigated genetic predisposition to COVID-19 is low.

One of the candidates with potential to influence susceptibility to SARS-CoV-2 infection and COVID-19 severity is CC chemokine receptor 5 (CCR5; OMIM acc. 
No. 601373). CCR5 acts as a co-receptor for HIV-1 entry into cells as well as cell-to-cell virus transmission during infection. Variability within the CCR5 gene plays an important role in resistance against HIV-1 infection. The CCR5 resistant variant (rs333) comprises the deletion of nucleotides 794-825 (amino acids 175-185). The resulting frameshift mutation generates a novel 31 AA inclusion and premature stop codon, producing truncated protein (Liu et al. 1996). Known as CCR5 32 , this genetic variant significantly reduces promoter activity, impairs CCR5 cell-surface expression and fully protects against HIV-1 infection in homozygous subjects (Ellwanger et al. 2020).

The importance of CCR5 in the pathogenesis of COVID-19 has been highlighted in two recent studies. Given the structural similarities between HIV-1 and SARS-CoV-2, the anti-AIDS agent enfuvirtide has been proposed as a potential inhibitor of SARS-CoV-2 entry into cells (Kliger and Levanon 2020). In a pilot study by Pattersson et al. (2020), a leronlimab-mediated CCR5 blockade was shown to improve inflammation markers and generate extreme reductions in plasma viremia. Furthermore, upregulation of CCR5 has been confirmed in COVID-19 patients (Ray et al. 2020).

Although the abovementioned studies have done much to highlight the importance of CCR5 in SARSCoV-2 infection, if there is some protective effects of CCR5 32 against COVID-19 have yet to be examined.

To address this deficit in the knowledge, our study focused on genotyping the CCR5 I/D ( $\triangle 32$, rs333) polymorphism in a total of 420 subjects, all testing positive for the presence of SARS-CoV-2 infection during the first wave of the disease in the Czech Republic (approx. 03/2020 - 06/2020). All these subjects were SARS-CoV-2 negative at the time of the DNA sample collection. Adult subjects from the DNA bank of the post-MONICA study were used as controls (for more details, see Cifkova et al. 2010, Hubacek et al. 2009). No information on COVID-19 infections in these subjects was available. Written informed consent was provided by all subjects involved in the study, with the protocol approved by the ethics committee of the participating institution.

Controls and patients were comparable with regard to age $(48 \pm 11$ years in controls and $44 \pm 15$ years in patients), prevalence of females (53.4\% vs. $54.7 \%$ ) and prevalence of diabetes ( $8.2 \%$ vs. $7.8 \%)$. However, there were significantly less hypertonic individuals in the group of patients $(13.3 \%$ vs. $22.4 \% ; \mathrm{P}=0.0001)$.
DNA were isolated from whole EDTA blood. The CCR5 rs333 polymorphism was genotyped using the oligos 5' TCTCAAAAAGAAGGTCTTCATTACACC and 5' TTCGACACCGAAGCAGAGTTTTTAGG. A PCR product of $172 \mathrm{bp}$ is characteristic for the wildtype untruncated sequence and $140 \mathrm{bp}$ for the minor deletion allele. PCR was performed on an DYAD Disciple PCR device (MJ Research, Reno, Nevada, USA); all chemicals were produced by Fermentas International, Burlington, Ontario, Canada.

After quality checks, genotypes were obtained from 2,404 controls, 164 SARS-CoV-2-positive/COVID19-asymptomatic patients and 252 SARS-CoV-2positive/COVID-19-symptomatic patients (Table 1).

We found $21 \%$ of the general population were carriers of at least one CCR5 $\Delta 32$ allele. Representing a population allele frequency of $11.4 \%$, this finding is almost identical to that of a previous study by Drabek and Petrek (1998). They found $21.3 \%$ of 386 Czech subjects were carriers of the CCR5 $\Delta 32$ allele. Our data on genotype distribution and population frequency in the Czech population correspond with results from neighboring populations in Poland (Zwolińska et al. 2013) or Germany (Hütter et al. 2015).

There were no differences between the entire group of SARS-CoV-2-positive subjects and population controls in respect of CCR $5 \triangle 32$ deletion carriers $(19.5 \%$ vs. $21.0 \%, \mathrm{P}=0.48)$.

Importantly, however, we observed a weak but significant trend in the frequency of CCR5 $\triangle 32$ allele carriers $(\mathrm{P}=0.03$; one-sided Cochran-Armitage trend test $)$ between groups (Table 1). According to our expectations, the highest number of CCR5 $\Delta 32$ carriers was found in SARS-CoV-2-positive/COVID-19-asymptomatic subjects $(23.8 \%)$ and the lowest in SARS-CoV-2-positive/COVID19 -symptomatic patients $(16.7 \%)$, with frequency in the control population in the middle $(21.0 \%)$.

How the CCR5 $\triangle 32$ allele exactly protects against COVID-19 is not known. However, our results are in agreement with a summary of the indirect evidence (Mehlotra 2020), which indicates a promising new function of CCR5 beyond HIV-1/AIDS pathology.

Previously reported interethnic and interpopulation differences could have a certain background in CCR5 32 prevalence (Libert et al. 1998). While the allele is most frequent in Northern-European Caucasians (approx. 16\%), only about $5 \%$ of Southern Europeans (Sardinia) are carriers, highlighting a significant northsouth trend. In Asians and black Africans, carriers of the 
allele are completely absent. It is assumed the mutation originated from a single case only, quickly expanding, which suggests this deletion holds an important selection advantage (Libert et al. 1998). The absence of the
CCR5 532 deletion among Asians and black Africans may partially explain the increased COVID-19 prevalence and mortality observed in these ethnic groups (Hippisley-Cox et al. 2020).

Table 1. Distribution of CCR5 32 (rs333) genotypes in controls and SARS-CoV-2-positive subjects.

\begin{tabular}{lccccccc}
\hline CCR5 & \multicolumn{2}{c}{$\begin{array}{c}\text { COVID-19 } \\
\text { asymptomatic }\end{array}$} & \multicolumn{2}{c}{$\begin{array}{c}\text { Controls } \\
\text { (population) }\end{array}$} & \multicolumn{2}{c}{$\begin{array}{c}\text { COVID-19 } \\
\text { symptomatic }\end{array}$} & P \\
\hline$r s 333$ & $\mathrm{~N}$ & $\%$ & $\mathrm{~N}$ & $\%$ & $\mathrm{~N}$ & $\%$ & \\
$I / I$ & 125 & 76.2 & 1899 & 79.0 & 210 & 83.3 & \\
$I / D$ & 36 & 22.0 & 464 & 19.3 & 40 & 15.9 & $0.17^{*}$ \\
$D / D$ & 3 & 1.8 & 41 & 1.7 & 2 & 0.8 & \\
$+D$ & 39 & 23.8 & 505 & 21.0 & 42 & 16.7 & $0.03^{\#}$ \\
$I / I$ & 125 & 76.2 & 1899 & 79.0 & 210 & 83.3 & \\
\hline
\end{tabular}

* $3 \times 2$ chi-square test for I/I vs. +D subjects, ${ }^{*}$ One-sided Cochran-Armitage trend test, I=insertion; D=deletion.

Generally, ligands binding to chemokine receptors influence susceptibility to infectious diseases and their clinical manifestations (Ellwanger et al. 2020). The CCR5 32 genetic variant has the potential to modify the CCR5-mediated organism response to many viral pathogens, including influenza and hepatitis viruses, cytomegalovirus as well as coronaviruses. While no functional receptor has been detected on cell surfaces in CCR5 32 homozygotes, reduced CCR5 expression has been observed in heterozygotes (Wu et al. 1997, Venkatesan et al. 2002). Therefore, it would appear this mutation acts as a natural model of complete CCR5 inhibition. Over-activation of the immune system, which is a hallmark of severe COVID-19 cases (Mehta et al. 2020, Paces et al. 2020), can be treated by CCR5 inhibition (Kliger and Levanon 2020, Pattersson et al. 2020). Mehlortra (2020) have summarized the results published thus far on the potential importance of $\Delta 32$ within CCR5, along with some other SNPs affecting CCR5 expression. They speculate that CCR5 inhibition may be of importance in COVID-19 treatment.

It is clear that genetic predisposition plays an important role in COVID-19 pathogenesis. However, the studies published thus far on the subject are not only scarce, but typically lack replication. Several publications (Bellone and Calvisi 2020, Yamamoto et al. 2020) highlight the importance of common insertion/deletion polymorphisms within the angiotensin-converting enzyme, with others (Ovsyannikova et al. 2020) proposing genes for vitamin D receptor, HFE and MBL, among others, as potential candidates.
Our results are in agreement with the findings of a genome-wide association study carried out by the Severe Covid-19 GWAS Group (2020). They detected two signals associated with severe COVID-19. The strongest signal was located within the AB0 blood-group system but, most importantly, the second strongest signal was localized at the $3 p 21.31$ loci in the vicinity of CCR5 and a number of other chemokine receptors (Mehlotra 2020).

It is acknowledged that male sex, increased age, comorbidities (hypertension, obesity, diabetes, cancer) and non-white ethnicity influence the course of severe COVID-19 disease (Hippisley-Cox et al. 2020). With regard to the effect of ethnicity, differences in genetic background may be of major importance. That Caucasians are attributed with the highest population frequency of CCR $5 \Delta 32$ seems to provide a partial explanation for these differences.

Therefore, in our view, knowledge of the host genomic factors that increase susceptibility or resistance to SARS-CoV-2 infection and COVID-19 severity is important to provide patients with a simple, quick and cost-effective test aimed at identifying individual DNA polymorphisms, which is likely to improve the timely prediction of COVID-19 complications and improve patient care.

We conclude that the $\Delta 32$ deletion within the CCR 5 gene, most commonly found in Caucasian populations, may potentially protect against symptomatic COVID-19. To validate and extend the findings reported here, a larger study involving also severe COVID-19 patients is needed. 


\section{Conflict of Interest}

There is no conflict of interest.

\section{Acknowledgements}

This study was supported by Ministry of Health, Czech Republic - Conceptual Development of Research Organisation (Institute for Clinical and Experimental Medicine - IKEM, IN 00023001).

\section{References}

BELLONE M, CALVISI SL: ACE polymorphism and COVID-19-related mortality in Europe. Mol Med (Berl) 98: 1505-1509, 2020. https://doi.org/10.1007/s00109-020-01981-0

BEREKAA MM: Insights into the COVID-19 pandemic: Origin, pathogenesis, diagnosis, and therapeutic interventions. Front Biosci (Elite Ed) 13: 117-139, 2021. https://doi.org/10.2741/874

CASANOVA JL: Human genetic basis of interindividual variability in the course of infection. Proc Natl Acad Sci U S A 112: E7118-E7127, 2015. https://doi.org/10.1073/pnas.1521644112

CÍFKOVÁ R, SKODOVÁ Z, BRUTHANS J, ADÁMKOVÁ V, JOZÍFOVÁ M, GALOVCOVÁ M, WOHLFAHRT P, KRAJCOVIECHOVÁ A, POLEDNE R, STÁVEK P, LÁNSKÁ V: Longitudinal trends in major cardiovascular risk factors in the Czech population between 1985 and 2007/8. Czech MONICA and Czech post-MONICA. Atherosclerosis 211: 676-681, 2010. https://doi.org/10.1016/j.atherosclerosis.2010.04.007

DRÁBEK J, PETREK M: 32 bp deletion in CCR-5 gene and human immunodeficiency virus epidemic in the Czech Republic. Acta Virol 42: 121-122, 1998.

ELHABYAN A, ELYAACOUB S, SANAD E, ABUKHADRA A, ELHABYAN A, DINU V: The role of host genetics in susceptibility to severe viral infections in humans and insights into host genetics of severe COVID-19: A systematic review. Virus Res 289: 198163, 2020. https://doi.org/10.1016/j.virusres.2020.198163

ELLWANGER JH, KULMANN-LEAL B, KAMINSKI VL, RODRIGUES AG, BRAGATTE MAS, CHIES JAB: Beyond HIV infection: Neglected and varied impacts of CCR5 and CCR5 32 on viral diseases. Virus Res 286: 198040, 2020. https://doi.org/10.1016/j.virusres.2020.198040

HIPPISLEY-COX J, YOUNG D, COUPLAND C, CHANNON KM, TAN PS, HARRISON DA, ROWAN K, AVEYARD P, PAVORD ID, WATKINSON PJ: Risk of severe COVID-19 disease with ACE inhibitors and angiotensin receptor blockers: Cohort study including 8.3 million people. Heart 106: 1503-1511, 2020. https://doi.org/10.1136/heartjnl-2020-317393

HUBACEK JA, PITHA J, ADAMKOVA V, LANSKA V, POLEDNE R: A common variant in the FTO gene is associated with body mass index in males and postmenopausal females but not in premenopausal females. Czech postMONICA and 3PMFs studies. Clin Chem Lab Med 47: 387-390, 2009. https://doi.org/10.1515/CCLM.2009.109

HÜTTER G, BLÜTHGEN C, ELVERS-HORNUNG S, KLÜTER H, BUGERT P: Distribution of the CCR5-delta32 deletion in Southwest Germany. Anthropol Anz 72: 303-309, 2015. https://doi.org/10.1127/anthranz/2015/0479

KLIGER Y, LEVANON EY: Cloaked similarity between HIV-1 and SARS-CoV suggests an anti-SARS strategy. BMC Microbiol 3: 20, 2003. https://doi.org/10.1186/1471-2180-3-20

LIBERT F, COCHAUX P, BECKMAN G, SAMSON M, AKSENOVA M, CAO A, CZEIZEL A, CLAUSTRES M, DE LA RÚA C, FERRARI M, FERREC C, GLOVER G, GRINDE B, GÜRAN S, KUCINSKAS V, LAVINHA J, MERCIER B, OGUR G, PELTONEN L, ROSATELli C, ET AL.: The deltaccr5 mutation conferring protection against HIV-1 in Caucasian populations has a single and recent origin in Northeastern Europe. Hum Mol Genet 7: 399-406, 1998. https://doi.org/10.1093/hmg/7.3.399

LIU R, PAXTON WA, CHOE S, CERADINI D, MARTIN SR, HORUK R, MACDONALD ME, STUHLMANN H, KOUP RA, LANDAU NR: Homozygous defect in HIV-1 coreceptor accounts for resistance of some multiplyexposed individuals to HIV-1 infection. Cell 86: 367-377, 1996. https://doi.org/10.1016/S0092-8674(00)80110-5

MEHLOTRA RK: Chemokine receptor gene polymorphisms and COVID-19: Could knowledge gained from HIV/AIDS be important? Infect Genet Evol 85: 104512, 2020. https://doi.org/10.1016/j.meegid.2020.104512

MEHTA P, MCAULEY DF, BROWN M, SANCHEZ E, TATTERSALL RS, MANSON JJ; HLH ACROSS SPECIALITY COLLABORATION, UK: COVID-19: consider cytokine storm syndromes and immunosuppression. Lancet 395: 1033-1034, 2020. https://doi.org/10.1016/S0140-6736(20)30628-0 
OVSYANNIKOVA IG, HARALAMBIEVA IH, CROOKE SN, POLAND GA, KENNEDY RB: The role of host genetics in the immune response to SARS-CoV-2 and COVID-19 susceptibility and severity. Immunol Rev 296: 205-219, 2020. https://doi.org/10.1111/imr.12897

PACES J, STRIZOVA Z, SMRZ D, CERNY J: COVID-19 and the immune system. Physiol Res 69: 379-388, 2020. https://doi.org/10.33549/physiolres.934492

PATTERSON BK, SEETHAMRAJU H, DHODY K, CORLEY MJ, KAZEMPOUR K, LALEZARI J, PANG APS, SUGAI C, MAHYARI E, FRANCISCO EB, ET AL.: CCR5 inhibition in critical COVID-19 patients decreases inflammatory cytokines, increases CD8 T-cells, and decreases SARS-CoV2 RNA in plasma by day 14. Int J Infect Dis 103: 25-32. https://doi.org/10.1016/j.ijid.2020.10.101

RAY PR, WANGZHOU A, GHNEIM N, YOUSUF MS, PAIGE C, TAVARES-FERREIRA D, MWIRIGI JM, SHIERS S, SANKARANARAYANAN I, MCFARLAND AJ, NEERUKONDA SV, DAVIDSON S, DUSSOR G, BURTON MD, PRICE TJ: A pharmacological interactome between COVID-19 patient samples and human sensory neurons reveals potential drivers of neurogenic pulmonary dysfunction. Brain Behav Immun 89: 559-568, 2020. https://doi.org/10.1016/j.bbi.2020.05.078

SEVERE COVID-19 GWAS GROUP, ELLINGHAUS D, DEGENHARDT F, BUJANDA L, BUTI M, ALBILLOS A, INVERNIZZI P, FERNÁNDEZ J, PRATI D, BASELLI G, ET AL.: Genomewide association study of severe covid-19 with respiratory failure. N Engl J Med 383: 1522-1534, 2020. https://doi.org/10.1056/NEJMoa2020283

VAŠKŮ A: Covid-19 infection and the host genetic predisposition: Does it exist? Physiol Res 69: 511-514, 2020. https://doi.org/10.33549/physiolres.934504

VENKATESAN S, PETROVIC A, VAN RYK DI, LOCATI M, WEISSMAN D, MURPHY PM: Reduced cell surface expression of CCR5 in CCR5Delta 32 heterozygotes is mediated by gene dosage, rather than by receptor sequestration. J Biol Chem 277: 2287-2301, 2002. https://doi.org/10.1074/jbc.M108321200

WU L, PAXTON WA, KASSAM N, RUFFING N, ROTTMAN JB, SULLIVAN N, CHOE H, SODROSKI J, NEWMAN W, KOUP RA, MACKAY CR: CCR5 levels and expression pattern correlate with infectability by macrophage-tropic HIV-1, in vitro. J Exp Med 185: 1681-1691, 1997. https://doi.org/10.1084/jem.185.9.1681

YAMAMOTO N, ARIUMI Y, NISHIDA N, YAMAMOTO R, BAUER G, GOJOBORI T, SHIMOTOHNO K, MIZOKAMI M: SARS-CoV-2 infections and COVID-19 mortalities strongly correlate with ACE1 I/D genotype. Gene 758: 144944, 2020. https://doi.org/10.1016/j.gene.2020.144944

ZWOLIŃSKA K, KNYSZ B, RYBKA K, PAZGAN-SIMON M, GĄSIOROWSKI J, SOBCZYŃSKI M, GŁADYSZ A, PIASECKI E: Protective effect of CCR5- $\triangle 32$ against HIV infection by the heterosexual mode of transmission in a Polish population. AIDS Res Hum Retroviruses 29: 54-60, 2013. https://doi.org/10.1089/aid.2011.0362 